\title{
ANALISIS RASIO KINERJA KEUANGAN PROFITABILITAS PT WIJAYA KARYA (PERSERO) TBK. PERIODE 2014 - 2018
}

\author{
Irwin Ananta Vidadaa, Ratiyah ${ }^{\mathrm{b}}$, Denny Ericac, Hartantid \\ $a, b, c, d$ Universitas Bina Sarana Informatika, Jl. Kamal Raya No 18 Ringroad Barat, \\ Cengkareng, Jakarta Barat,DKI Jakarta,Indonesia \\ "(irwin.iav@bsi.ac.id)
}

\begin{abstract}
ABSTRAK
Dalam memperkirakan tingkat risiko dalam menghadapi ketidakpastian, perusahaan dapat memanfaatkan analisa laporan keuangan sebagai alat perumusan rencana masa depan. Melalui analisis laporan keuangan perusahaan mampu mengetahui estimasi pencapaian kinerja dari semua divisinya. Penelitian ini melakukan analisis rasio profitabilitas untuk mengetahui kinerja keuangan perusahaan. Tujuan pada penelitian ini ialah guna mengetahui maupun melakukan identifikasi terhadap kinerja keuangan PT Wijaya Karya (Persero) Tbk Periode 2014 hingga 2018.Dalam penelitian ini pengumpulan data digunakan melalui melalui cara observasi dan studi pustaka dengan mengacu data kinerja keuangan pada perusahaan. Metode penelitian padapenulisan ini dilakukan melalui analisa rasio dengan pendekatan kuantitatif. Pengamatan data terhadap laporan keuangan PT Wijaya Karya (Persero) Tbk periode 2014 - 2018 menunjukkan bahwa secara umum selama kurun waktu pengamatan data rasio tahun tersebut maka pada rasio GPM, NPM, OIM, ROE dan EPS mengalami fluktuasi turun dan naik serta pada rasio ROA cenderung mengalami penurunan.
\end{abstract}

Kata kunci: Analisis rasio, Kinerja Keuangan, Profitabilitas

\begin{abstract}
In estimating the risk of uncertainty, companies can use financial report analysis as the formulation tool for plans. By using financial report analysis, companies are capable of knowing the estimated work achievement of all division in the company. To find out the company's financial performance, in this case, analysis is done through profitability ratio analysis (Rentability). The purpose of this study was to find out and identify the financial performance of PT Wijaya Karya (Persero) Tbk 2014 period until 2018. In this study, data collection was used through means of observation and literature by referring to financial performance data on the company. The research method is done through ratio analysis with a quantitative approach. Observation of data on the financial statements of PT Wijaya Karya (Persero) Tbk for the period 2014 - 2018 reveal that in general during the period of observation of the year data ratio, the GPM, NPM, OIM, ROE and EPS ratios fluctuated down and up, the ROA ratio tends to decrease.
\end{abstract}

Keywords: Ratio analysis, financial performance, profitability 


\section{PENDAHULUAN}

PT Wijaya Karya (Persero) Tbk atau disingkat dengan sebutan WIKA dibentuk dari proses nasionalisasi perusahaan Belanda bernama Naamloze Vennotschap Technische Handel Maatschappij en Bouwbedijf Vis en Co. atau NV Vis en Co. Berdasarkan Peraturan Pemerintah No. 2 tahun 1960 dan Surat Keputusan Menteri Pekerjaan Umum dan Tenaga Listrik (PUTL) No. 5 tanggal 11 Maret 1960, dengan nama Perusahaan Negara Bangunan Widjaja Karja. Perkembangan signifikan pertama adalah di tahun 1972, dimana pada saat itu nama Perusahaan Negara Bangunan Widjaja Karja berubah menjadi PT Wijaya Karya. WIKA kemudian berkembang menjadi sebuah kontraktor konstruksi dengan menangani berbagai proyek penting. Seiring berjalannya waktu, berbagai tahap pengembangan kerap kali dilakukan untuk terus tumbuh serta menjadi bagian dari pengabdian WIKA bagi perkembangan bangsa melalui jasa-jasa konstruksi yang tersebar di berbagai penjuru negeri (Humas PT Wijaya Karya (Persero) Tbk, 2019).

Ketertarikan penulis meneliti PT Wijaya karya (Persero) Tbk dikarenakan perusahaan ini masuk ke dalam sembilan perusahaan kontraktor terbesar dan terbaik di
Indonesia selain itu PT Wijaya karya (persero) Tbk juga familiar di masyarakat dan bersejarah dengan senantiasa berkontribusi dalam berbagai pembangunan infrastruktur di Indonesia melalui kiprahnya di bidang jasa konstruksi (Lia, 2018). Selain itu, sebagai perusahaan sukses berusia puluhan tahun menimbulkan ketertarikan pula bagi penulis untuk mencermati kondisi perkembangan dan kinerja keuangannya saat ini dengan mengacu data lima tahun terakhir 2014 - 2018 yang informasinya disediakan oleh laman web bursa efek indonesia (PT Bursa Efek Indonesia, 2019).

Sebagaimana perusahaan besar lainnya dalam menjalankan roda bisnis perusahaan membutuhkan rencana bisnis yang baik untuk tetap senantiasa memperoleh keuntungan. Dalam menghadapi ketidakpastian dan resiko usaha di masa depan tentu membutuhkan proses antisipasi atas keadaan tersebut. Perusahaan dapat menggunakan alat bantu berupa tehnik analisa laporan keuangan yang mampu membantu perusahaan untuk memberikan estimasi besaran tingkat resiko maupun ketidakpastian agar dapat menghasilkan perumusan rencana yang optimal.

Melalui tulisan ini penulis berupaya menyajikan analisa laporan 
keuangan menggunakan rasio profitabilitas (Rentabilitas) untuk mengukur kemampuan perusahaan dalam mendapatkan keuntungan. Beberapa indikator yang bisa dilakukan melalui rasio-rasio profitabilitas/Rentabilitas, melalui sejumlah rasio-rasio tersebut akan mampu untuk mengukur kinerja operasi keuangan perusahaan.

Werner. R. Murhadi dalam Sari (2017) menjelaskan bahwa Operating Income merupakan kemampuan manajemen guna mengubah aktivitasnya menjadi laba. Dalam korelasi pengukuran kinerja, dijelaskan pula bahwa Net Profit Margin mampu memberikan gambaran mengenai kemampuan perusahaan dalam menghasilkan laba neto yang diraih dari setiap penjualannya. Rasio ini mengindikasikan pendapatan bersih perusahaan atas penjualan.

Selain itu, masih terkait pengukuran kinerja keuangan, Werner menjelaskan bahwa Return On Asset mencerminkan seberapa besar return yang dihasilkan atas setiap rupiah uang yang ditanamkan dalam bentuk aset (Sari, 2017). Pakar lainnya menjelaskan pula jika Return on Equity (ROE) merupakan rasio yang mampu mengukur laba bersih sesudah pajak atau Earning After Interest and Tax (EAIT) dengan modal sendiri. Melalui rasio ini mampu menunjukan efisiensi penggunaan modal sendiri. Demikian pada penggunaan rasio Earning Per Share Of Common Stock (EPS) yang mana melalui rasio dapat mengukur keberhasilan manajemen dalam mencapai keuntungan bagi pemegang saham (Kasmir, 2012). Teori lainya mengemukakan juga bahwa Gross Profit Margin (GPM) merupakan rasio laba kotor terhadap penjualan yang mampu mengukur efisiensi produksi dan penentuan harga jual (Prastowo, 2011).

Dengan mengkorelasikan rasiorasio yang kemukakan oleh para pakar tersebut diatas, penelitian ini memilih sejumlah rasio-rasio pengukur kinerja keuangan antara lain GPM (Gross Profit Margin), NPM (Net Profit Margin), OIM (Operating Income Margin), EPS (Earning Per Common Share), ROE (Return on Equity), dan ROA (Return On Asset) untuk digunakan dalam mengukur kinerja keuangan pada PT Wijaya Karya (persero) TBk.

Melalui penelitian ini diharapkan mampu memberikan kontribusi informasi mengenai kinerja keuangan pada PT Wijaya Karya (persero) Tbk periode $2014 \quad$ sampai 2018 menggunakan rasio profitabilitas (Rentabilitas). 
TELAAH LITERATUR

\section{Pentingnya Laporan Keuangan}

Dalam pengertian sederhana, laporan keuangan adalah laporan yang menunjukan kondisi keuangan perusahaan pada saat ini atau dalam suatu periode tertentu. Laporan keuangan mampu memberi petunjuk mengenai kondisi terkini keadaan keuangan perusahaan seperti pada tanggal tertentu yang ditunjukan melalui neraca maupun hasil kondisi keuangan secara periodik yang ditunjukan melalui laporan rugi laba. Terdapat laporan keuangan setiap tiga bulan, enam bulan untuk kepentingan internal sedangkan laporan keuangan yang buat secara formal dilakukan satiap satu tahun sekali (Kasmir, 2012).

Pada umumnya, laporan keuangan terdiri dari Neraca dan Perhitungan rugi laba serta laporan perubahan modal. Laporan padaneraca menunjukan jumlah aktiva, hutang maupun modal di suatu perusahaan pada tanggal tertentu, sedangkan laporan rugi laba menunjukan hasil yang dicapai perusahaan serta biaya selama periode tertentu, dan laporan perubahan modal memberikan petunjuk sumber dan penggunaan yang terkait perubahan modal (Munawir, 2014).
Keterkaitan Laporan keuangan merupakan obyek dari analisis terhadap laporan keuangan. Oleh karena itu, memahami latar belakang penyusunan dan penyajian laporan keuangan merupakan langkah yang sangat penting sebelum menganalisis laporan keuangan itu sendiri. (Prastowo, 2011). Penysunan dan penyajian laporan keuangan secara tepat dan benar pada setiap periodenya berguna sebagai dasar bagi proses pengambilan keputusan.

\section{Jenis Laporan Keuangan}

Guna melengkapi pengetahuan mengenai laporan keuangan maka perlu pula untuk mengetahui jenisjenis laporan keuangan. Pada umumnya laporan keuangan terdiri dari:

\section{Neraca}

Neraca adalah laporan keuangan yang memberikan informasi mengenai posisi keuangan (aktiva, kewajiban, dan ekuitas) perusahaan pada saat tertentu (Prastowo, 2011). Neraca adalah laporan yang sistematis tentang aktiva, hutang serta modal dari suatu perusahaan pada suatu saat tertentu (Munawir, 2014). Sementara itu, Kasmir (2012) mengemukakan bahwa neraca merupakan salah satu laporan keuangan yang terpenting bagi perusahaan yang menunjukan posisi 
keuangan berupa aktiva, utang dan modal perusahaan pada saat tertentu. Secara garis besar komponen neraca dapat di jabarkan sebagai berikut:

a) AktivaLancar

Merupakan uang kas dan aktiva lainnya yang dapat diharapkan untuk dicairkan atau ditukarkan menjadi uang tunai, dijual atau di konsumer dalam periode berikutnya, paling lama satu tahun atau dalam perputaran kegiatan perusahaan yang normal (Munawir, 2014). Aktiva lancar terdiri dari rekening Kas, bank, investasi jangka pendek, piutang wesel, piutang dagang, pesediaan, penghasilan yang masih harus diterima, biaya dibayar dimuka.

b) AktivaTidak Lancar

Merupakan aktiva yang mempunyai umur kegunaan relatip permanen atau jangka panjang, mempunyai umur ekonomis lebih dari satu tahun atau tidak akan habis dalam satu kali perputaran operasi perusahaan (Munawir, 2014). Aktiva tidak lancar terdiri dari rekening investasi jangka panjang baik beupa saham, obligasi, aktiva tetap non operasional, pendanaan khusus. Pada contoh lainnya bisa berupa aktiva tetap seperti tanah, bangunan, mesin, inventaris, kendaraan. Terdapat pula aktiva tetap tidak berwujud yang meliputi hak cipta, merek dagang, biaya pendirian, lisensi, goodwil dan lainnya. Selain tersebut aktiva tidak lancar lainnya juga pada beban yang ditangguhkan seperti biaya penelitin, biaya pemasaran, diskonto obligasi, biaya pembukaan perusahaan dan sebagainya. Bagian lain dari aktiva tidak lancar juga bisa berupa kekayaan yang belum dapat diklasifikasikan seperti gedung dalam proses, tanah dalam penyelesaian, piutang jangka panjang dan lainnya.

c) Hutang lancar

Merupakan kewajiban keuangan perusahaan yang pelunasannya atau pembayaran akan dilakukan dalam jangka pendek (satu tahun sejak tanggal neraca) dengan menggunakan aktiva lancar yang dimiliki perusahaan (Munawir, 2014). Hutang lancar terdiri dari rekening hutang dagang, hutang wesel, hutang pajak, biaya yang masih harus dibayar, hutang jangka panjang yang akan jatuh tempo, penghasilan diterima dimuka.

d) Hutang Jangka Panjang Merupakan kewajiban keuangan yang jangka waktu pembayarannya masih jangka panjang, lebih dari satu tahun sejak tanggal neraca (Munawir, 2014). Hutang jangka panjang terdiri dari 
rekening hutang obligasi, hutang hipotik maupun pinjaman jangka panjang lainnya.

e) Modal

Merupakan hak atau bagian yang dimiliki oleh pemilik perusahaan yang ditunjukan dalam pos modal (modal saham), surplus dan laba ditahan. Pengelompokan rekening modal terdiri dari rekening modal itu sendiri, laba ditahan, jika dalam persero bisa lebih terklasifikasi lagi seperti rekening modal saham biasa, modal saham prioritas, agio saham dan sebagainya.

\section{Laporan Rugi Laba}

Merupakan suatu laporan yang sistematis mengenai pendapatanpendapatan, biaya-biaya maupun laba atau rugi yang diraih oleh suatu perusahaan selama masa periode tertentu. Susunan bagian laporan laba rugi yang bisa kita pahami dapat mengacu dengan pendapat para ahli diantaranya menurut Munawir (2014) secara umum susunan laporan rugi laba dapat di jabarkan pembagiannya sebagai berikut:
a) Bagian
pertama
yang menunjukkan posisi penghasilan yang diraih dari usaha pokok perusahaan diikuti dengan pengurangan harga pokok dari barang atau jasa yang terjual sehingga didapat nilai laba kotor penjualan.

b) Bagian kedua yang menunjukkan sejumlah biayabiaya operasional yang terjadibaik berupa Biaya Penjualan maupun biaya Umum/Administrasi.

c) Bagian ketiga memberikan informasi mengenai hasil-hasil yang didapat diluar operasi pokok perusahaan dengan pengurangan biaya-biaya yang terjadi diluar operasi usaha utama perusahaan

d) Bagian keempat yang menunjukkan tentang selisih laba atau rugi secara sehingga bisa diketahui perolehan laba bersih sebelum dipotong oleh pajak pendapatan.

Bentuk laporan laba rugi dengan mengacu pendapat para ahli diantaranya menurut Kasmir (2012) dapat kita pahami, yaitu:

a) Bentuk tunggal (single step)

Bentuk tunggal atau single step merupakan suatu bentuk gabungan yang terdiri dari jumlah seluruh penghasilan, baik usaha pokok (operasional) maupun diluar usahya pokok (non operasional) dijadikan satu, kemudian hal yang sama juga pada jumlah biaya usaha pokok dan 
yang diluar usaha pokok pun dijadikan satu.

b) Bentuk majemuk (multiple step)

Bentuk majemuk atau multiple step merupakan suatu bentuk dengan adanya pemisahan antara komponen usaha pokok usaha dengan komponen yang diluar usaha pokok. Pada tahap awal terlebih dahulu dikurangi antara penghasilan pokok dengan biaya pokok, kemudian tahap selanjutnya baru ditambahkan hitungannya dengan hasil kalkulasi pengurangan penghasilan di luar pokok usaha oleh biaya-biayanya yang terjadi di luar pokok usaha tersebut.

\section{Laporan Perubahan Modal}

Menurut Kasmir laporan perubahan modal merupakan laporan yang berisi jumlah maupun jenis modal yang dimiliki oleh perusahaan kemudian juga pada laporan ini memberikan penjelasan mengenai sebab-sebab perubahannya (Kasmir, 2012).

\section{Laporan Arus Kas}

Menurut Kasmir laporan arus kas merupakan laporan yang memberikan informasi mengenai semua aspek pada kegiatan perusahaan terkait dengan kas baik yang berpengaruh langsung maupun tidak (Kasmir, 2012).
5. Laporan catatan atas laporan keuangan

Laporan yang memberikan informasi dengan kebutuhan tambahan penjelasan pada suatu laporan keuangan tertentu jika diperlukan(Kasmir, 2012).

\section{Tujuan Laporan Keuangan}

Dalam memahami apakah yang menjadi tujuan laporan keuangan maka kita dapat mengacu dengan pendapat ahli (Kasmir, 2012) ialah sebagai berikut yaitu:

1. Memberikan informasi mengenai jenis dan jumlah aktiva (harta) yang dimiliki perusahaan saat ini.

2. Memberikan informasi mengenai jenis dan jumlah kewajiban dan modal yang dimiliki perusahaan pada saat ini.

3. Memberikan informasi mengenai jenis dan jumlah pendapatan yang diperoleh pada suatu periode tertentu.

4. Memberikan informasi mengenai jumlah biaya dan jenis biaya yang dikeluarkan perusahaan dalam suatu periode tertentu.

5. Memberikan informasi mengenai perubahan perubahan yang terjadi 
Vidada, dkk - Analisis Rasio Kinerja Keuangan Profitabilitas...

terhadap aktiva, pasiva dan modal perusahaan.

6. Memberikan informasi mengenai kinerja manajemen perusahaan dalam suatu periode.

7. Memberikan informasi mengenai catatan-catatan atas laporan keuangan.

8. Informasi keuangan lainnya.

\section{Pengertian Rasio Keuangan}

Merupakan kegiatan dalam melakukan perbandingan diantara angka-angka yang terdapat pada laporan keuangan dengan cara membagi satu angka dengan angka lainnya baik yang berasal dari satu komponen yang sama maupun antar komponen dalam laporan keuangan. Kemudian diperbandingkan baik dapat berupa angka-angka pada suatu periode saja maupun membandingkannya pada sejumlah periode(Kasmir, 2012).

\section{Bentuk-Bentuk Rasio Keuangan}

Manajemen perusahaan dapat melakukan sejumlah metode maupun opsional pilihan dalam perhitungan rasio terhadap laporan keuangan (Financial Statement) guna menilai kinerja keuangannya (Financial Performance). Pihak manajemen perusahaan menggunakan serta memilih tiap-tiap rasio keuangan yang memiliki kegunaan, tujuan maupun arti tertentu dalam kesesuainya dengan kepentingan pengambilan keputusan serta penentuan kebijakan perusahaan (Vidada, 2018). Ada beberapa cara untuk mengukur rasio keuangan perusahaan (Kasmir, 2012) sebagai berikut:

1. Likuiditas (Liquidity Ratio)

Rasio untuk mengukur gambaran kemampuan perusahaan guna memenuhi kewajiban jangka pendek perusahaan.

\section{Aktivitas (Activity)}

Rasio untuk mengukur tingkat efiseinsi pemanfaatan dari sumber daya perusahaan baik itu penjualan, persediaan, penagihan piutang dan sebagainya dalam melaksanakan aktivitas keseharian.

\section{Profitabilitas (Profitability Ratio)}

Rasio untuk mengukur gambaran kemampuan perusahaan dalam menghasilkan keuntungan dalam suatu periode tertentu. Menurut kasmir rasio profitabilitas memiliki padanan substansi yang sama dengan rasio rentabilitas. Rasio rentabilitas terbagi dua yakni rentabilitas ekonomi berupa perbandingan laba usaha dengan seluruh modal (baik modal sendiri maupun asing) dan rentabilitas usaha (sendiri) yakni berupa 
perbandingan laba bagi pemilik dengan jumlah modalnya sendiri.

\section{Rasio Leverage (Leverage Ratio) atau rasio Solvabilitas}

Rasio untuk mengukur atau memberikan gambaran kemampuan perusahaan dalam membiayai kegiatan usahanya dengan memenuhi pembayaran hutangnyabaik hutang jangka pendek maupun jangka panjang.

\section{Rasio Pertumbuhan (Growth Ratio)}

Rasio untuk mengukur kemampuan perusahaan guna mempertahankan tingkat posisi ekonomi perusahaan di tengah pertumbuhan perekonomian maupun sektor usahanya.

6. Rasio Penilaian (Valuation Ratio) Rasio yang memberikan gambaran kemampuan bagi manajemen mengenai penciptaan nilai pasar diatas biaya yang dikeluarkan untuk investasinya.

\section{Pengertian Rasio Profitabilitas}

Rasio profitabilitas menurut kasmir adalah rasio guna menilai kemampuan perusahaan dalam memperoleh keuntungan atau laba pada suatu periode tertentu(Kasmir, 2012). Menurut Dermawan dan Djahotman Rasio profitabilitas atau rasio rentabilitas merupakan
"Pengukuran kemampuan dalam memperoleh laba dengan menggunakan aset atau modal perusahaan." Semakin tinggi pada rasio ini semakin baik karena menunjukan laba yang diperoleh berarti semakin besar (Dermawan Sjahrial dan Djahotman Purba, 2013).

\section{Tujuan Rasio Profitabilitas}

Menurut Kasmir tujuan penggunaan rasio profitabilitas bagi perusahaan maupun pihak luar perusahaan (Kasmir, 2012), antara lain:

1. Melakukan pengukuran atau penghitungan laba yang diperoleh perusahaan dalam satu periode tertentu.

2. Melakukan penilaian posisi laba perusahaan tahun sebelumnya dengan tahun sekarang.

3. Melakukan penilaian perkembangan laba dari waktu ke waktu.

4. Melakukan penilaian besarnya laba bersih sesudah pajak dengan modal sendiri.

5. Melakukan pengukuran produktivitas seluruh dana perusahaan yang digunakan baik modal pinjaman maupun modal sendiri. 
Vidada, dkk - Analisis Rasio Kinerja Keuangan Profitabilitas...

METODE

Pendekatan

penyelesai-an

masalah pada penelitian ini

dilakukan secara kuantitatif

menggunakan perhitungan aritmatika

dalam mengintepretasikan data

analsia rasio ke dalam hubungan

ekonomis yang menggambarkan

kinerja keuangan pada PT Wijaya

Karya (Persero) Tbk melalui perbandingan antar tahun sebelumnya maupun standar industri rasio profitabilitas. Penelitian ini dilakukan sejumlah metode antara lain pertama studi literatur melalui kajian materi ulasan seputar analisa rasio keuangan disertai pula dengan penelusuran penopang materi lainnya, kedua menggunakan metode observasi berupa pengamatan terhadap data kinerja keuangan PT Wijaya Karya (Persero) Tbk dengan memanfaatkan sumber data sekunder berupa data laporan keuangan perusahaan yang di publikasikan melalui laman web https://www.idx.co.id/ Bursa Efek Indonesia (BEI) (PT Bursa Efek Indonesia, 2019). Ketiga dengan cara Metode Komparatif, penulis membandingkan data maupun fakta temuan yang kemudian melalui proses hitung dan analisis menjadi hasil analisa yang memberikan penilaian dan pengambilan kesimpulan atas fakta temuan.

\section{HASIL DAN PEMBAHASAN \\ Data KeuanganPT Wijaya Karya (Persero) Tbk}

Berdasarkan hasil penelitian pada PT Wijaya Karya (Persero) Tbk, penulis memperolehdata keuangan pada tahun 2014 sampai 2018 sebagai berikut:

Tabel 1. Data Keuangan PT Wijaya Karya (Persero) Tbk

Per 31 Desember 2014- 2018

(Dalam jutaan rupiah)

\begin{tabular}{lrrrrr}
\hline \multicolumn{1}{c}{ Ket } & \multicolumn{1}{c}{2014} & \multicolumn{1}{c}{2015} & \multicolumn{1}{c}{2016} & \multicolumn{1}{c}{2017} & \multicolumn{1}{c}{2018} \\
\hline Jumlah Asset & 15.915 .162 & 19.602 .406 & 31.096 .539 & 45.683 .774 & 56.896 .030 \\
Jumlah & 4.978 .758 & 5.438 .101 & 12.498 .715 & 14.631 .825 & 15.384 .920 \\
Ekuitas & & & & & \\
Penjualan & 12.463 .216 & 13.620 .101 & 15.668 .833 & 26.176 .403 & 21.003 .556 \\
Laba Kotor & 1.794 .327 & 1.943 .063 & 2.605 .939 & 2.876 .234 & 2.375 .777 \\
Laba Usaha & 1.400 .919 & 1.513 .905 & 2.079 .004 & 1.462 .391 & 1.736 .924 \\
Laba Sebelum & 1.145 .890 & 1.098 .082 & 1.230 .490 & 1.462 .391 & 1.158 .306 \\
$\begin{array}{l}\text { Pajak } \\
\text { Laba Setelah }\end{array}$ & 750.796 & 703.005 & 1.147 .145 & 1.356 .115 & 1.057 .161 \\
$\begin{array}{l}\text { Pajak } \\
\text { Laba Per }\end{array}$ & 122,10 & 114,32 & 127,89 & 151,18 & 117,86 \\
Lembar & & & & & \\
Saham & & & & & \\
\hline Sumber: idx.co.id & & & & &
\end{tabular}


Mengacu perolehan data keuangan bersumber dari publikasi Neraca dan Laporan Laba Rugi PT Wijaya karya (Persero) Tbk periode 2014 sampai 2018 dari laman web (PT Bursa Efek Indonesia, 2019) menunjukkan bahwa terjadi peningkatan jumlah asset secara signifikan dari tahun 2014 sampai pada tahun 2018 menjadi sebesar $357,50 \%$. Pada ekuitas pun juga mengalami penambahan dari tahun demi tahun sejak 2014 sampai pada tahun 2018 menjadi sebesar 309\%.

Demikian pula pada data penjualan pun mengalami kenaikan pada 2018 jmenjadi 168,80\% dibanding data penjualan pada 2014 meski peningkatan pada tahun 2018 ini pun sudah mengalami penurunan jika dibanding tahun 2017. Demikian pula pada laba kotor nilai tertinggi berada pada tahun 2017, sedang pada laba usaha peningkatan dengan nilai tertinggi pada tahun 2016 namun pada perhitungan laba sebelum dan sesudah pajak laba tertinggi berada pada tahun 2017 . Laba per lembar saham mengalami peningkatan tertinggi sejak tahun 2014 itu pada tahun 2017 kemudian menjadi turun pada angka 117,86 di tahun 2018 .

\section{Rasio Profitabilitas PT Wijaya Karya (Persero) Tbk}

Mengukur kemampuan potensi perusahaan dalam menghasilkan laba menggunakan rasio profitabilitas dapat digunakan beberapa rasio yang menjadi alat guna melakukan analisa maupun intepretasi atas data tersebut. Guna mengukur Rasio kinerja operasi perusahaan seperti mengukur tingkat perolehan penghasilan, mndapatkan laba serta keefisienan perusahaan mampu diukur melalui rasio-rasio profitabilitas yang diantaranya sebagai berikut:

1. Gross Profit Margin (GPM), merupakan rasio laba kotor terhadap penjualan guna mengukur efisiensi produksi dan penentuan harga jual (Prastowo, 2011).

2. Net Profit Margin (NPM), merupakan rasio untuk mengukur nilai laba yang dihasilkan oleh setiap nilai penjualan sehingga seluruh efisiensi, baik produksi, administrasi, pemasaran, pendanaan, penentuan harga dan manajemen pajak menjadi lebih terukur (Prastowo, 2011). 
Tabel 2. Data Gross Profit Margin (GPM)

PT Wijaya Karya (Persero) Tbk

Per 31 Desember 2014 - 2018

(Dalam jutaan rupiah)

\begin{tabular}{lccc}
\hline Tahun & Gross Profit & Total Revenues & Gross Profit Margin \\
\hline 2014 & $1,794,327$ & 12.463 .216 & $14,40 \%$ \\
2015 & $1,943,063$ & 13.620 .101 & $14,27 \%$ \\
2016 & $2,605,939$ & 15.668 .833 & $16,63 \%$ \\
2017 & $2,876,234$ & 26.176 .403 & $10,99 \%$ \\
2018 & $2,375,777$ & 21.003 .556 & $11,31 \%$ \\
\hline
\end{tabular}

Sumber: Hasil Pengolahan Data (2019)

Tabel 3. Data Net Profit Margin (NPM)

PT Wijaya Karya (Persero) Tbk

Per 31 Desember $2014-2018$

(Dalam jutaan rupiah)

\begin{tabular}{lccc}
\hline Tahun & Profit for the period & Total Revenues & Net Profit Margin \\
\hline 2014 & 750.796 & 12.463 .216 & $6,02 \%$ \\
2015 & 703.005 & 13.620 .101 & $5,16 \%$ \\
2016 & 1.147 .145 & 15.668 .833 & $7,32 \%$ \\
2017 & 1.356 .115 & 26.176 .403 & $5,18 \%$ \\
2018 & 1.057 .161 & 21.003 .556 & $5,03 \%$ \\
\hline
\end{tabular}

Sumber: Hasil Pengolahan Data (2019)

3. Operating Income Margin (OIM) merupakan rasio guna memberikan gambaran mengenai efisiensi perusahaan pada kegiatan utama perusahaan, angka laba yang digunakan dalam rasio ini berasal dari kegiatan pokok perusahaan.

4. Return on Equity (ROE) merupakan rasio yang mengukur laba bersih sesudah pajak atau Earning After Interest and Tax (EAIT) dengan modal sendiri. Melalui rasio ini mampu menunjukan efisiensi penggunaan modal sendiri (Kasmir, 2012).
5. Return on asset (ROA) menurut Werner Murhadi yang nukil melalui paparan Dian Indah Sari dalam tulisan jurnalnya menjelaskan bahwa rasio tersebut mencerminkan seberapa besar return yang dihasilkan atas setiap rupiah uang yang ditanamkan dalam bentuk aset (Sari, 2017).

6. Earning Per Share of Common Stock (EPS) merupakan rasio untuk mengukur keberhasilan manajemen dalam mencapai keuntungan bagi pemegang saham (Kasmir, 2012). 
Tabel 4. Data Operating Income Margin (OIM) PT Wijaya Karya (Persero) Tbk Per 31 Desember 2014 - 2018

(Dalam jutaan rupiah)

\begin{tabular}{cccc}
\hline Tahun & Operating Profit & Total Revenues & Operaing Income Margin \\
\hline 2014 & 1.400 .919 & 12.463 .216 & $11,24 \%$ \\
2015 & 1.513 .905 & 13.620 .101 & $11,12 \%$ \\
2016 & 2.079 .004 & 15.668 .833 & $13,27 \%$ \\
2017 & 1.462 .391 & 26.176 .403 & $5,587 \%$ \\
2018 & $1,736,924$ & 21.003 .556 & $8,27 \%$ \\
\hline
\end{tabular}

Sumber: Hasil Pengolahan Data (2019)

Tabel 5. Data Return on Equity (ROE)

PT Wijaya Karya (Persero) Tbk

Per 31 Desember 2014 - 2018

(Dalam jutaan rupiah)

\begin{tabular}{lccc}
\hline Tahun & Profit for the period & Total Equity & Return On Equity \\
\hline 2014 & 750.796 & 4.978 .758 & $15,08 \%$ \\
2015 & 703.005 & 5.438 .101 & $12,93 \%$ \\
2016 & 1.147 .145 & 12.498 .715 & $9,18 \%$ \\
2017 & 1.356 .115 & 14.631 .825 & $9,27 \%$ \\
2018 & 1.057 .161 & 15.384 .920 & $6,87 \%$ \\
\hline
\end{tabular}

Sumber: Hasil PengolahanData (2019)

Tabel 6. Data Return on Asset (ROA)

PT Wijaya Karya (Persero) Tbk

Per 31 Desember $2014-2018$

(Dalam jutaan rupiah)

\begin{tabular}{llll}
\hline Tahun & Profit for the period & Total Assets & Return on Assets \\
\hline 2014 & 750.796 & 15.915 .162 & $4,72 \%$ \\
2015 & 703.005 & 19.602 .406 & $3,59 \%$ \\
2016 & 1.147 .145 & 31.096 .539 & $3,69 \%$ \\
2017 & 1.356 .115 & 45.683 .774 & $2,97 \%$ \\
2018 & 1.057 .161 & 56.896 .030 & $1,86 \%$ \\
\hline
\end{tabular}

Sumber: Hasil PengolahanData (2019)

Tabel 7. Data Earning Per Share of Common Stock (EPS)

PT Wijaya Karya (Persero )Tbk

Per 31 Desember $2014-2018$

\begin{tabular}{rccccc}
\hline Rasio & 2014 & 2015 & 2016 & 2017 & 2018 \\
\hline EPS (Rp) & 122.10 & 114.32 & 127.89 & 151.18 & 117.86 \\
\hline
\end{tabular}

Sumber: idx.co.id

Berikut ringkasan data tabel umum Ratio atau Rata-rata industri rasio-rasio/data acuan pengukuran yang dikemukakan Niki Lukviarman kinerja keuangan dengan rasio dalam bukunya (Lukviarman, 2006) profitabiltas dengan mengacu Standar sebagai berikut:

Tabel 7. Data Rasio Kinerja Operasi Keuangan 
PT Wijaya Karya (Persero) Tbk

Per 31 Desember 2014 - 2018

(Dalam persentase)

\begin{tabular}{cccccccc}
\hline No & Rasio & 2014 & 2015 & 2016 & 2017 & 2018 & Standar Industri \\
\hline 1 & GPM (\%) & 14,40 & 14,27 & 16,63 & 10,99 & 11,31 & 24,90 \\
2 & NPM (\%) & 6,02 & 5,16 & 7,32 & 5,18 & 5,03 & 3,92 \\
3 & OIM (\%) & 11,24 & 11,12 & 13,27 & 5,59 & 8,27 & 10,80 \\
4 & ROE (\%) & 15,08 & 12,93 & 9,18 & 9,27 & 6,87 & 8,32 \\
5 & ROA (\%) & 4,72 & 3,59 & 3,69 & 2,97 & 1,86 & 5,98 \\
6 & EPS (Rp) & 122,10 & 114,32 & 127,89 & 151,18 & 117,86 & - \\
\hline
\end{tabular}

Sumber: idx.co.id

\section{Pembahasan}

Mengacu berdasarkan pada data hasil perhitungan terhadap dinamika besaran rasio profitabilitas pada laporan keuangan PT Wijaya Karya (Persero) Tbk dari tahun 2014 sampai 2018 melalui perbandingan besaran nilai angka rasio dengan standar industri rasio profitabilitas (Lukviarman, 2006) maka analisa yang dapat penulis uraikan ialah sebagai berikut:

1. GPM

Mengacu berdasar hasil perhitungan rasio keuangan maka melalui analisa yang penulis hendak tunjukan bahwa:

a) Pada tahun 2014 dengan penjualan sebesar Rp 1dapat mampu member laba kotor sebesar Rp. 0,144.

b) Pada tahun 2015 dengan penjualan sebesar Rp 1 dapat mampu memberi laba kotor sebesar Rp. 0,143.

c) Pada tahun 2016 dengan penjualan sebesar $\operatorname{Rp} 1$ dapat mampu memberi laba kotor sebesar Rp. 0,166.

d) Pada tahun 2017 dengan penjualan sebesar $R p 1$ dapat mampu memberi laba kotor sebesar Rp. 0,110.

e) Pada tahun 2018 dengan penjualan sebesar $\mathrm{Rp} 1$ dapat mampu memberi laba kotor sebesar Rp. 0,113.

Maka berdasar pada nilai GPM tahun 2014-2018 mengindikasikan tingkat GPM PT Wijaya Karya (Persero) Tbk mengalami fluktuasi turun dan naik, hal ini mengindikasikan kinerja keuangan PT Wijaya Karya (Persero) Tbk mengalami turun dan naik pada efisiensi produksi dan penentuan harga jual dalam rentang waktu tersebut. Bahkan jika di komparasikan antara tahun 2014 dan 2018 maka untuk penjualan sebesar Rp 1 mampu memberi kontribusi laba kotor yang lebih besar pada tahun 2014 sebesar Rp 0144 jika dibandingkan data GPM pada tahun 2018 yang hanya sebesar 
Rp 0,113. Secara umum rasio persentase GPM ini tahun demi tahun masih dibawah Standar umum Ratio atau Rata-rata industri sebesar $24,90 \%$.

\section{NPM}

Mengacu berdasar hasil perhitungan rasio keuangan maka melalui analisa yang penuli shendak tunjukan bahwa:

a) Pada tahun 2014 dengan penjualan sebesar $\operatorname{Rp} 1$ dapat mampu memberi laba neto sebesar Rp. 0,060.

b) Pada tahun 2015 dengan penjualan sebesar $\operatorname{Rp} 1$ dapat mampu memberi laba neto sebesar Rp. 0,052

c) Pada tahun 2016 dengan penjualan sebesar $\mathrm{Rp} 1$ dapat mampu memberi laba neto sebesar Rp. 0,073.

d) Pada tahun 2017 dengan penjualan sebesar $\mathrm{Rp} 1$ dapat mampu memberi laba neto sebesar Rp. 0,052.

e) Pada tahun 2018 dengan penjualan sebesar Rp 1 dapat mampu memberi laba neto sebesar Rp. 0,050.

Maka berdasar pada nilai NPM tahun 2014-2018 mengindikasikan tingkat NPM PT Wijaya Karya (Persero) Tbk mengalami fluktuasi turun dan naik, hal ini mengindikasikan kinerja keuangan PT Wijaya Karya (Persero) Tbk mengalami turun dan naik pada seluruh efisiensi produksi, admnistrasi, pendanaan, penentuan harga, pemasaran dan manajemn pajak. Bahkan jika di komparasikan antara tahun 2014 sampai 2018 maka untuk penjualan sebesar Rp 1 mampu memberi kontribusi laba netotertinggi pada tahun 2016 sebesar Rp 0,073 jika dibandingkan pada tahun 2018 yang turun menjadi sebesar Rp 0,050. Secara umum rasio persentase NPM ini tahun demi tahun semuanya berada diatas Standar umum Ratio atau Rata-rata industri sebesar 3, 92 \%. Posisi NPM tahun 2014 - 2018 di kisaran 5 sampai 7\% pada tiap-tiap tahunnya.

\section{OIM}

Mengacu berdasar hasil perhitungan rasio keuangan maka melalui analisa yang penulis hendak tunjukan bahwa:

a) Pada tahun 2014 dengan penjualan sebesar $\mathrm{Rp} 1$ dapat mampu memberi laba usaha sebesar Rp. 0,112.

b) Pada tahun 2015 dengan penjualan sebesar $\mathrm{Rp} 1$ dapat mampu memberi laba usaha sebesar Rp. 0,111.

c) Pada tahun 2016 dengan penjualan sebesar $\mathrm{Rp} 1$ dapat 
mampu memberi laba usaha sebesar Rp. 0,133.

d) Pada tahun 2017 dengan penjualan sebesar $\mathrm{Rp} 1$ dapat mampu memberi laba usaha sebesar Rp. 0,056.

e) Pada tahun 2018 dengan penjualan sebesar $\mathrm{Rp} 1$ dapat mampu memberi laba usaha sebesar Rp. 0,083.

Maka berdasar pada nilai OIM tahun 2014-2018 mengindikasikan tingkat OIM PT Wijaya Karya (Persero) Tbk mengalami fluktuasi turun dan naik, hal ini mengindikasikan kinerja keuangan PT Wijaya Karya (Persero) Tbk mengalami turun dan naik pada efisiensi kegiatan utama perusahaan. Bahkan jika di komparasikan antara tahun 2014 sampai 2018 maka untuk penjualan sebesar $\mathrm{Rp} 1$ mampu memberi kontribusi laba usaha tertinggi pada tahun 2016 sebesar Rp 0,133 jika dibandingkan pada tahun 2018 yang turun menjadi sebesar Rp 0,083 .

Data rasio OIM terkecil terjadi pada tahun 2017 yang mana penjualan $\mathrm{Rp} 1$ memberi kontribusi laba usaha sebesar Rp 0,056. Pada sumber data keuangan PT Wijaya karya (Persero) Tbk (PT Bursa Efek Indonesia, 2019) pun tidak mencantum secara jelas nilai laba usaha (Operating Profit), namun penulis mengambil data turunannya dari laba bersih sebelum pajak karena pada data keuangan tersebut juga tidak tercantum nilai beban dan pendapatan lain-lain sebagai pengurang maka nilai laba usaha yang merupakan selisih laba kotor dikurangi dengan biaya usaha dalam konteks ini bernilai sama dengan laba bersih sebelum pajak. Kecilnya nilai laba usaha pada tahun 2017 disebabkan karena besarnya atau terdapatnya ketidakefisienan pada beban usaha (Operating Expenses) yang besar.

Nilai rasio Persentase OIM ini dari tahun 2014 - 2016 berada diatas rata-rata standar industri yang sebesar 10,80 \%, rasio tertinggi sebesar $13,27 \%$ di tahun 2016. Pada tahun 2017 dan 2018 terjadi penurunan yang mana posisi OIM ini menjadi turun di bawah persentase rata-rata industri dan yang terendah pada tahun 2017 sebesar 5,59\%.

4. ROE

Mengacu berdasar hasil perhitungan rasio keuangan maka melalui analisa yang penulis hendak tunjukan bahwa:

a) Pada tahun 2014 dengan investasi modal oleh pemegang saham sebesar $\mathrm{Rp} 1$ dapat mampu memberi laba neto sebesar Rp. 0,151. 
b) Pada tahun 2015 dengan investasi modal oleh pemegang saham sebesar Rp 1 dapat mampu memberi laba neto sebesar Rp. 0,129

c) Pada tahun 2016 dengan investasi modal oleh pemegang saham sebesar $\operatorname{Rp} 1$ dapat mampu memberi laba neto sebesar Rp. 0,092

d) Pada tahun 2017 dengan investasi modal oleh pemegang saham sebesar Rp 1 dapat mampu memberi laba neto sebesar Rp. 0,093

e) Pada tahun 2018 dengan investasi modal oleh pemegang saham sebesar Rp 1 dapat mampu memberi laba neto sebesar Rp. 0,069

Maka berdasar pada nilai $\mathrm{ROE}$ tahun 2014-2018 mengindikasikan tingkat ROE PT Wijaya Karya (Persero) Tbk mengalami turun dari $15,08 \%$ di tahun 2014 menjadi 9,18\% di tahun 2016, kemudian dari tahu 2016 ke tahun 2017 naik sedikit menjadi 9,27 \% dan turun lagi di tahun 2018 menjadi 6,87\%.

Hal ini mengindikasikan kinerja keuangan PT Wijaya Karya (Persero) Tbk masih mengalami fluktuasi terhadap efisiensi atas penggunan modal sendiri. Bahkan jika dikomparasikan antara tahun 2014 sampai 2018 maka tingkat $\mathrm{ROE}$ tertinggi pada tahun 2014 sebesar $15,08 \%$ dan terendah pada tahun 2018 sebesar 6,87\%. Hal tersebut terjadi dikarenakan semakin membesarnya total ekuiti dari tahun demi tahun tidak diikuti oleh perbandingan yang sama pada laba bersih setelah pajak yang dari tahun demi tahun masih fluktuasi turun dan naik.

Nilai rasio Persentase ROE ini nyaris setiap tahunnya berada diatas rata-rata standar industri sebesar $8,32 \%$, rasio tertinggi sebesar $15,08 \%$ pada tahun 2014. Namun pada tahun 2018 posisi nilai rasio turun menjadi $6,87 \%$ menyebabkan posisi berada dibawah rata-rata standar industri.

5. ROA

Mengacu berdasar hasil perhitungan rasio keuangan maka melalui analisa yang penulis hendak tunjukan bahwa:

a) Pada tahun 2014 dengan aset sebesar Rp 1 dapat mampu memberi laba neto sebesar Rp. 0,0472 .

b) Pada tahun 2015 dengan aset sebesar Rp 1 dapat mampu memberi laba neto sebesar Rp. 0,0359 .

c) Pada tahun 2016 dengan aset sebesar Rp 1 dapat mampu memberi laba neto sebesar Rp. 0,0369 . 
d) Pada tahun 2017 dengan aset sebesar Rp 1 dapat mampu memberi laba neto sebesar Rp. 0,0296 .

e) Pada tahun 2018 dengan aset sebesar Rp 1 dapat mampu memberi laba neto sebesar Rp. 0,0185 .

Maka berdasar pada nilai ROA tahun 2014-2018 mengindikasikan tingkat ROA PT Wijaya Karya (Persero) Tbk mengalami turun dari 4, $72 \%$ di tahun 2014 menjadi 1, 86\% di tahun 2018. Hal ini mengindikasikan kinerja keuangan PT Wijaya Karya (Persero) Tbk masih mengalami kecendrungan menurun terhadap efisiensi atas penggunan aset sendiri. Bahkan jika di komparasikan antara tahun 2014 sampai 2018 maka tingkat ROA tertinggi pada tahun 2014 sebesar $4,72 \%$ dan terendah pada tahun 2018 sebesar $1,86 \%$.

Hal tersebut terjadi dikarenakan semakin membesarnya total aset secara signifikan dari tahun demi tahun namun tidak di ikuti oleh perbandingan yang sama pada pendapatan bersih (net income) yang dari tahun demi tahun masih fluktuasi turun dan naik. Nilai rasio Persentase ROA ini pada setiap tahunnya berada di bawah rata-rata industri 5,98\% bahkan posisi rasio terendah berada pada tahun 2018 sebesar $1,86 \%$.
6. EPS

Mengacu berdasar hasil perhitungan rasio keuangan maka melalui analisa yang penulis hendak tunjukan bahwa:

a) Pada tahun 2014 dengan jumlah saham sebanyak satu lembar dapat mampu memberi laba/ keuntungan bagi pemegang saham Rp. 122,10.

b) Pada tahun 2015 dengan jumlah saham sebanyak satu lembar mampu memberi laba/ keuntungan bagi pemegang saham sebesar Rp. 114,32.

c) Pada tahun 2016 dengan jumlah saham sebanyak satu lembar mampu memberi laba/ keuntungan bagi pemegang saham sebesar Rp. 127,89.

d) Pada tahun 2017 dengan jumlah saham sebanyak satu lembar mampu memberi laba / keuntungan bagi pemegang saham sebesar Rp. 151,18.

e) Pada tahun 2018 dengan jumlah saham sebanyak satu lembar mampu memberi laba / keuntungan bagi pemegang saham sebesar Rp. 117,86.

Maka berdasar pada nilai EPS tahun 2014-2018 mengindikasikan nominal EPS PT Wijaya Karya (Persero) Tbk mengalami fluktuasi turun dan naik. Namun secara rentang waktu tersebut EPS turun 
dari Rp 122,10 di tahun 2014 menjadi Rp 117,86 di tahun 2018. EPS tertinggi pada tahun 2017 sebesar Rp 151,18, EPS terendah pada tahun 2015 sebesar Rp 114,32. Hal ini mengindikasikan kinerja keuangan PT Wijaya Karya (Persero) Tbk masih mengalami fluktuasi terhadap optimalisasi laba/ keuntungan yang di hasilkan melalui representasi jumlah saham yang beredar.

\section{KESIMPULAN, IMPLIKASI DAN KETERBATASAN PENELITIAN}

\section{Simpulan}

Berdasarkan pada ulasan dalam penelitianini maka yang dapat penulis simpulkan mengetahui mengenai kinerja keuanganpada PT Wijaya Karya (Persero) Tbk periode 2014 sampai 2018 menggunakan perhitungan dan analisa terhadap rasio profitabilitas adalah sebagai berikut:

1. GPM (Gross Profit Margin),

Pada rasio ini perusahaan mengalami fluktuasi turun dan naik, hal ini mengindikasikan kinerja keuangan PT Wijaya Karya (Persero) Tbk mengalami turun dan naik pada efisiensi produksi dan penentuan harga jual dalam rentang waktu tahun 2014 - 2018 tersebut.

Kinerja keuangan yang ditunjukan melalui rasio persentase
GPM ini tahun demi tahun masih berada dibawah Standar umum Ratio atau Rata-rata industri sebesar 24, 90 \%. Performa kinerja keuangan yang di tunjukan melalui nilai rasio Persentase GPM ini baru di kisaran antara 11 sampai $17 \%$ pada tiap tahunnya.

\section{NPM (Net Profit Margin)}

Pada rasio ini perusahaan mengalami fluktuasi turun dan naik, hal ini mengindikasikan kinerja keuanganPT Wijaya Karya (Persero) Tbk mengalami turun dan naik pada seluruh efisiensi produksi, admnistrasi, pendanaan, penentuan harga, pemasaran dan manajemn pajak dalam rentang waktu tahun 2014 - 2018 tersebut.

Kinerja keuangan rasio persentase NPM tahun demi tahun semuanya berada diatas standar umum ratio atau rata-rata industri sebesar 3, 92 \%. Performa kinerja keuangan yang di tunjukan melalui nilai rasio NPM tahun 2014 - 2018 di kisaran 5 sampai $7 \%$ pada tiap tahunnya.

\section{OIM (Operating Income Margin)}

Pada rasio ini perusahaan mengalami fluktuasi turun dan naik hal ini mengindikasikan kinerja keuangan PT Wijaya Karya (Persero) Tbk mengalami turun dan naik pada efisiensi atas kegiatan (operasi usaha) 
utama perusahaan dalam rentang waktu tahun 2014 - 2018 tersebut.

Kinerja keuangan rasio persentase OIM ini dari tahun 2014 2016 berada diatas rata-rata standar industri yang batas nilainya sebesar $10,80 \%$, rasio tertinggi sebesar 13 , 27 di tahun 2016. Pada tahun 2017 dan 2018 terjadi penurunan performa kinerjanya yang mana posisi OIM ini menjadi turun di bawah persentase rata-rata industri dan yang terendah pada tahun 2017 sebesar 5,59\%.

\section{ROE (Return on Equity)}

Pada rasio ini perusahaan mengalami fluktuasi turun dan naik hal ini mengindikasikan kinerja keuangan PT Wijaya Karya (Persero) Tbk masih mengalami fluktuasi terhadap efisiensi atas penggunan modal sendiri perusahaan. Hal tersebut terjadi dikarenakan semakin membesarnya total ekuiti dari tahun demi tahun namun tidak di ikuti oleh perbandingan yang sama pada laba bersih setelah pajak yang dari tahun demi tahun senantiasa fluktuasi turun dan naik nilainya dalam rentang waktu tahun 2014 - 2018 tersebut.

Kinerja keuangan rasio persentase ROE ini nyaris setiap tahunnya berada diatas rata-rata standar industri sebesar $8,32 \%$, rasio tertinggi sebesar $15,08 \%$ pada tahun 2014. Namun pada tahun 2018 posisi nilai rasio turun menjadi $6,87 \%$ menyebabkan posisi berada dibawah rata-rata standar industri.

\section{ROA (Return on Asset)}

Pada rasio ini perusahaan mengalami kecendrungan menurun. $\mathrm{Hal}$ ini mengindikasikan kinerja keuangan PT Wijaya Karya (Persero) Tbk masih mengalami kecendrungan menurun terhadap efisiensi atas penggunan aset sendiri. Hal tersebut terjadi dikarenakan semakin membesarnya total aset secara signifikan dari tahun demi tahun namun tidak di ikuti oleh perbandingan yang sama pada pendapatan bersih (net income) yang dari tahun demi tahun masih fluktuasi turun dan naik nilainya dalam rentang waktu tahun 2014 2018 tersebut. Kinerja keuangan rasio persentase ROA ini pada setiap tahunnya berada di bawah rata-rata industri 5,98\% bahkan posisi rasio terendah berada pada tahun 2018 sebesar $1,86 \%$.

\section{EPS (Earning Per Share)}

Pada perbandingan rasio EPS ini perusahaan mengalami fluktuasi turun dan naik. Hal ini mengindikasikan kinerja keuangan PT Wijaya Karya (Persero) Tbk masih mengalami fluktuasi terhadap optimalisasi laba/keuntungan yang di hasilkan melalui representasi 
jumlah saham yang beredar dalam rentang waktu tahun 2014 - 2018 tersebut.

7. Melalui perhitungan dan analisa terhadap rasio profitabilitas bisa digunakan sebagai alat guna menilai perkembangan yang terjadi pada laba (keuntungan) perusahaandari waktu ke waktu, mengukur tingkat produktivitas seluruh penggunaan dana perusahaan baik itu dari modal pinjaman maupun yang berasal darimodal sendiri. Melalui optmimalisasi penelitian dan akurasi data diharapkanhasil analisa ini bisa membantu berkontribusi dalam proses pengambilan keputusan sehingga mampu lebih jelas dalam mencermati perkembangan yang terjadi atas kemajuan kinerja keuangan perusahaan.

\section{Keterbatasan Penelitian}

Untuk penelitian sejenis berikutnya guna mendapatkan informasi yang lebih menyeluruh dan lebih lengkap dari penelitian yang tersaji saat ini maka jauh lebih baik jika rentang durasi tahun perbandingan rasionya dapat di tentukan waktu yang lebih lama melebihi dari kurun waktu lima tahun yang menjadi keterbatasan data pengamatan pada penelitian ini.

\section{REFERENSI}

Dermawan Sjahrial dan Djahotman Purba. (2013). Analisis Laporan Keuangan (Kedua). Retrieved from

http//www.mitrawacanamedia.c om

Humas PT Wijaya Karya (Persero) Tbk. (2019). Tentang Perusahaan. Retrieved March 22, 2019, from http://www.wika.co.id/id/pages /who-we-are

Kasmir. (2012). Analisis Laporan Keuangan (5th ed.). Jakarta: PT Rajagrafindo Persada.

Lia, L. (2018). 9 Perusahaan Kontraktor Terbesar dan Terbaik di Indonesia. Retrieved May 9, 2019, from REAL ESTATE NEWS website:

https://www.spacestock.com/bl og/9-perusahaan-kontraktorterbesar-dan-terbaik-diindonesia/

Lukviarman, N. (2006). Dasar-Dasar Manajemen Keuangan. Padang: Andalas University Press.

Munawir. (2014). Analisa Laporan Keuangan (4th ed.). Yogyakarta: Liberty Yogyakarta.

Prastowo, D. (2011). Analisis Laporan Keuangan (Ketiga). Yogyakarta: UPP STIM YKPN.

PT Bursa Efek Indonesia. (2019). Ringkasan Kinerja Perusahaan Tercatat. Retrieved March 28, 2019, from PT Wijaya Karya (Persero) Tbk website: https://www.idx.co.id/datapasar/laporanstatistik/ringkasan-performaperusahaan-tercatat/

Sari, D. I. (2017). Analisis Kinerja Keuangan BCA Periode 20112015 Dengan Rasio 
Profitabilitas. Moneter, $I V($ No 2 Oktober), 113-120. Retrieved from

https://ejournal.bsi.ac.id/ejurn al/index.php/moneter/article/d ownload/2248/1688

Vidada, I. A. (2018). Mengukur Kinerja Keuangan PT Adaro Energy Tbk (ADRO) Melalui Perhitungan Rasio. Jurnal Administrasi Kantor, 6(ASM Bina Insani), 10. Retrieved from http:/ / ejournalbinainsani.ac.id/index.php/JAK $\mathrm{BI} /$ article/view/1016 